
CHAPTER 4

\title{
Climate, Environment and Lake Flixton
}

\author{
Barry Taylor, Simon Blockley, Ian Candy, Pete Langdon, Ian Matthews, \\ Adrian Palmer, Alex Bayliss and Nicky Milner
}

\section{Introduction}

At the time of occupation, Star Carr lay at the western end of Lake Flixton, a large shallow body of water that had formed in the eastern end of the Vale of Pickering. The lake forms an integral part of the story of Star Carr, providing the habitats for many of the animals that people hunted and the plants that they ate as food or used as materials. As it infilled, the peat that formed around the edges of the lake also created the conditions within which the archaeological evidence for the lives of these people was preserved. However, the lake has a far longer and more complex history that is bound up in the major climatic and environmental changes that accompanied the transition from the last cold period to the current Holocene interglacial warm period.

Over the past 120,000 years, since the last interglacial (MIS5e), there have been a series of major fluctuations in the Earth's climate (e.g. Rasmussen et al. 2014). It was towards the end of this period, during the Last Glacial Maximum, the last period of major ice advance, that the landforms within which Lake Flixton formed were first created. In Britain this is recognised as being part of a long cold period known as the Dimlington Stadial, based on a type-section of glacial deposits in East Yorkshire (Rose 1985), and dated to c. 30,000-16,000 BP (c. $28,000-14,000 \mathrm{BC}$ ). This was followed by a slow warming of the climate, punctuated by episodic climate shifts, that led into the start of the Holocene.

From a North Atlantic perspective, one of the most detailed records of these climate events is found in the Greenland ice-core records (Rasmussen et al. 2014) and is summarised in Figure 4.1. These records indicate a gradual warming after the Last Glacial Maximum, with rapid warming at c. 14,700 BP (12,700 BC), followed by another major cooling episode between c. 12,900 and 11,700 BP (10,900 and 9,700 BC; known in Britain as the Loch Lomond stadial, which is succeeded by the transition into our current Interglacial, the Holocene. In the Greenland record the warm episode is known as Greenland Interstadial 1 (GI1) and the cold transition is Greenland Stadial 1 (GS1), and as with the Dimlington Stadial they are thought to broadly equate to warm and cold periods in British and European records (the Lateglacial period consisting of the Windermere Interstadial and the Loch Lomond Stadial in the British sequence). Finally, the Greenland record suggests that the start of the Holocene was also climatically unstable with a series of short-lived but important cooling episodes notably

Figure 4 (page 39): Species of bulrush growing at the water's edge at Blakemere Moss, Delamere, Cheshire (Copyright Barry Taylor, CC BY-NC 4.0).

How to cite this book chapter:

Taylor, B., Blockley, S., Candy, I., Langdon, P., Matthews, I., Palmer, A., Bayliss, A. and Milner, N. 2018. Climate, Environment and Lake Flixton. In: Milner, N., Conneller, C. and Taylor, B. (eds.) Star Carr Volume 1: A Persistent Place in a Changing World, pp. 41-53. York: White Rose University Press. DOI: https://doi.org/10.22599/book1.d. Licence: CC BY-NC 4.0 


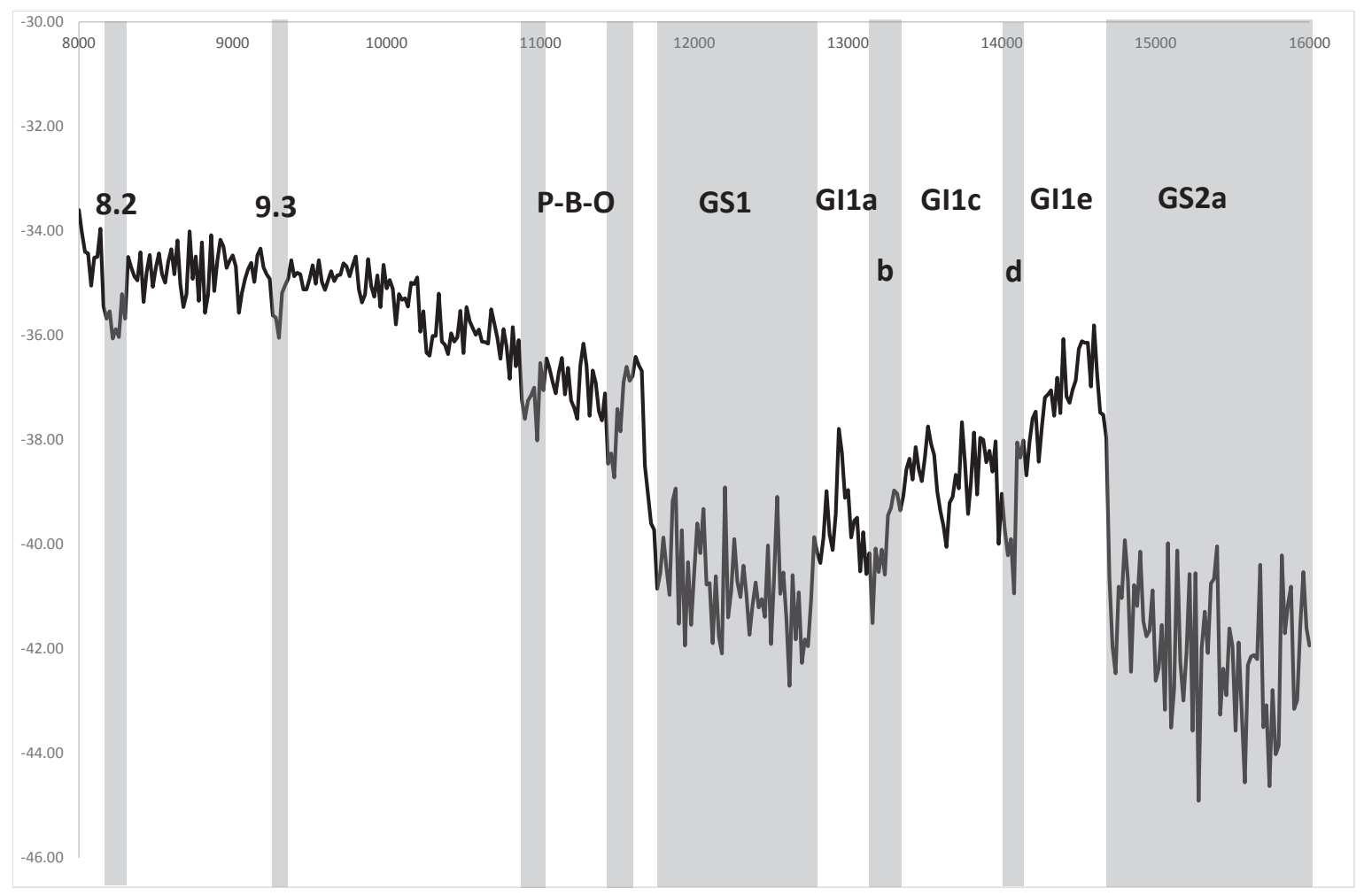

Figure 4.1: Climatic transitions in the Last Glacial to Interglacial from the $\delta^{18} \mathrm{O}(\% 0)$ Greenland ice core record, replotted from Rasmussen et al. (2014) in ice core years before present (BP (B2K)). Grey shaded areas indicate cold oscillations in the Late Glacial period (GS2 and GS1) and cooling episodes within the warmer GI1 interstadial (GI1b and d), along with short-lived cooling events in the Early Holocene. These are defined in the formal Greenland event stratigraphy and occur approximately at 11,400 BP (9400 BC), 9300 BP (7300 $\mathrm{BC})$ and $8200 \mathrm{BP}(6200 \mathrm{BC})$. A further event is that part of the oscillations in climate at the very start of the Holocene recorded in the NGRIP ice core at $\sim 11,100 \mathrm{BP}(9100 \mathrm{BC})$, but this is not formally recognised in the event stratigraphy (Copyright Simon Blockley, CC BY-NC 4.0).

the PBO (Pre-Boreal Oscillation at 11.4 ka BP (c. 9400 BC)), and the $9.3 \mathrm{ka} \mathrm{BP} \mathrm{(c.} 7300 \mathrm{BC}$ ) and $8.2 \mathrm{ka} \mathrm{BP} \mathrm{(c.}$ 6200 BC) events. Crucial to our story, these climatic events also had major effects on the environments around Lake Flixton, resulting in fluctuations in the lake-water level, and changing patterns of vegetation both within the lake and across the surrounding landscape.

However, the development of the environments within the lake was also driven by more local ecological factors. Shortly after the lake formed it was colonised by aquatic vegetation, leading to the formation of a carbonate sediment (marl) within the basin. From the start of the Holocene, peat began to form in shallow water close to the shore, whilst marl and detrital muds accumulated within the deeper part of the basin. This caused the depth of water to decrease (though the level of the lake essentially remained the same), and allowed wetland vegetation suited to increasingly shallow conditions to expand into the lake, a process known as hydroseral succession. Initially, this process would have been most apparent in the relatively shallower water around the edges of the lake, where the buildup of peat would have quickly brought the sediments close to and then above the surface of the lake. In response, plants suited to shallow or seasonally flooded environments would have expanded into these areas, before being replaced by fen species and trees (Figure 4.2). At the same time, aquatic and emergent vegetation suited to deeper, more permanent standing water would have begun to encroach further into the lake, gradually reducing the areas of open water. As sediments continued to form within the basin, this succession of wetland environments would have expanded further into the lake until, by the end of the Mesolithic, the lake no longer existed as a body of water and had been replaced by a mosaic of wetland environments punctuated by streams and small pools of standing water. 


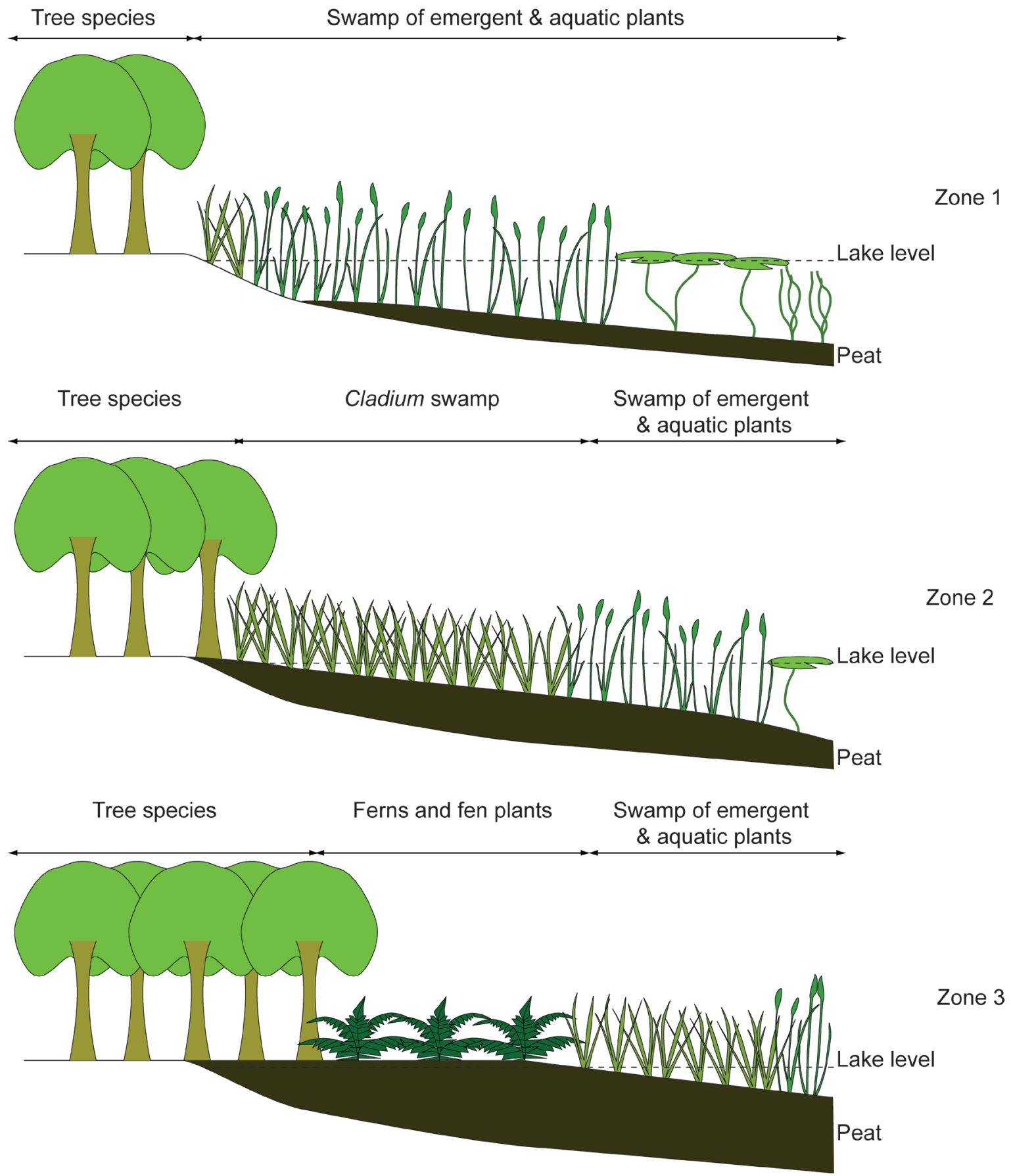

Figure 4.2: Generalised sequence of wetland environmental succession at the edge of lake Flixton (Zones 1-3 refer to the environmental sequence reported in Chapter 19) (Adapted from Taylor et al. 2017. Copyright Cambridge University Press (2017) reprinted with permission). 


\section{Understanding Lake Flixton}

The history of the lake and the surrounding landscape was already well known before the current project started. The lake itself had been identified in the late 1940s through the surveys carried out by John Moore, and in 1949 Harry Godwin published the first pollen profile from the area based on samples taken close to Moore's excavations on Flixton Island (Godwin 1949). The same year, Godwin and his doctoral student, Donald Walker, began a more extensive palaeoenvironmental survey of the surrounding landscape, recording the stratigraphy of the basin through a series of borehole transects, and using pollen and plant macrofossil analysis to establish the changing character of the lake and terrestrial vegetation (Walker and Godwin 1954). The results of this work were then tied into the relative chronology that had already been established for Late Glacial and Early Holocene climatic events in Northern Europe by relating the environmental record recorded at Lake Flixton to the environmental sequences previously recorded at European sites.

In the mid 1970s a more detailed study of the environments around the western side of the lake was carried out by Ed Cloutman as part of the Seamer Carr project (Cloutman 1988a). As part of this work, auger surveys were carried out along the north-west edge of the lake basin, mapping in detail the Mesolithic land surface and the shallower lake margins. The survey was extended in the following years to cover the western side of the lake, including some of the deeper parts of the basin, and eventually the Star Carr peninsula.

Whilst Walker and Godwin had already described the main sequence of wetland development within the lake, Cloutman sought to refine this by establishing the rate at which these environments developed around the Seamer Carr area (Cloutman 1988b). To do this he recorded eight pollen profiles from different locations within the lake margins and correlated these on the basis of common, chronological horizons. By comparing the points at which different environments formed at these different locations, Cloutman was then able to map wetland succession across the Seamer Carr area. Cloutman went on to adopt a similar approach at Star Carr in the mid 1980s, recording a series of pollen profiles at intervals through the lake margins (Cloutman and Smith 1988). These were correlated using radiocarbon dating, resulting in an absolute chronology for the development of the wetland environments at the site.

From the late 1980s onwards, palaeoenvironmental research continued, largely under the auspices of the Vale of Pickering Research Trust. Auger surveys continued to be carried out around the lake and pollen profiles were recorded from Flixton Island and Moore's Site 9 by Jim Innes (Lane and Schadla-Hall forthcoming). In the 1990s the environmental record was refined further through work carried out by Petra Dark (née Day) (Day 1996; Dark 1998a; 1988b), who established a more precise chronology for the development of the Early Mesolithic lake edge wetlands at Star Carr, and a more detailed record for the Late Glacial and Early Holocene development of the wider lake (Day 1996; Dark 1998c). Dark also showed that the wetland vegetation at Star Carr was deliberately burnt over prolonged periods during the occupation of the site, possibly as a form of environmental management (Dark 1998b). In the following years Gaynor Cummins identified further evidence for the deliberate burning of both the wetland and terrestrial vegetation at several other sites in the area, during both the Early and Late Mesolithic, demonstrating the apparent ubiquity of such practices within this landscape (Cummins 2003).

When brought together, the results of the different surveys that have been carried out within this landscape create a formidable body of data that tells us much about the character of the environments that formed within and around the lake. Our contribution to this record is twofold. First, is a detailed record of the palaeoclimate from the very final stages of the last cold period to the Early Holocene, and which spans the period of time that Star Carr was inhabited. This has been established through a programme of coring, and the analysis of chironomids (non-biting midges) and stable isotopes present in the lake sediments (see Chapter 18). Together, these provide proxies for temperature and precipitation within the local area during the time the sediments were forming. Dates for this record have been correlated with the chronology established for the occupation of Star Carr, allowing us to explore the relationship between episodes of climate change and patterns of human activity (Chapter 9). Second, is a more detailed record of the nature of the wetland environments that were forming at Star Carr (Chapter 19) and the dates at which these changed (see Chapter 17). The results of this work have been brought together with recent palaeoenvironmental surveys carried out in other parts of the basin (see Taylor 2012), and the earlier work undertaken by Dark (1988) and Cummins (2003) to provide a comprehensive record of the environmental and climatic history of Lake Flixton. 


\section{The origins of Lake Flixton}

During the Dimlington Stadial the North Sea Lobe of the British-Irish Ice Sheet advanced into the eastern end of the Vale of Pickering, extending at least as far as Seamer and Wykeham area (Catt 1991, 61; Catt 2007, 202). At the same time, the western end of the valley was blocked by a glacier at Ampleforth (Catt 2007, 194). With drainage at either end of the valley blocked, water accumulated within the Vale, creating the Glacial Lake Pickering, which probably existed between 19,000-15,000 BC (Kendall 1902, 499; Evans et al. 2016) (Figure 4.3).

As the glacier retreated from the eastern end of the Vale of Pickering, late in the Dimlington, it left a series of large irregular hollows (kettle holes) that were formed by the melting of blocks of ice that had become detached from the glacier, and ridges (terminal moraines and kames) formed by glacially transported material and sediment carried by meltwater streams (Franks 1987; Palmer et al. 2015). As the ice continued to retreat eastwards it deposited a large moraine at Filey, preventing the eastward drainage of water from the Vale into the sea (Catt 1987) with the rivers draining toward the south-west through the Kirkham gorge.

Water accumulated within the hollows left by the retreating glacial ice, creating a single body of water, Lake Flixton, from the start of the Windermere Interstadial at about $14.6 \mathrm{ka} \mathrm{BP}(12,600 \mathrm{BC})$, whilst the ridges and low mounds within and around the basins became small, hilly peninsulas and islands. As the climate warmed, aquatic and emergent vegetation quickly colonised the lake causing marl, a carbonate precipitate, to form within the basin (Dark 1998c), whilst grassland and willow scrub, followed by birch woodland became established over the dry ground (Dark 1998c). Around 12,900 BP (10,900 BC), the climate deteriorated with the onset of the Loch Lomond Stadial, which is broadly in phase with the abrupt cooling seen in key regional records at this time, such as the major cooling event, the Greenland stadial (GS1) seen in the Greenland ice cores (Figure 4.1). During this period aquatic vegetation became more sparse and the level of the lake fell, creating a series of separate basins (Palmer et al. 2015). The temperatures around Lake Flixton at this time would have been significantly colder than today with average summer temperatures as cold as $8^{\circ} \mathrm{C}$ (Chapter 18).

\section{The Early Holocene Lake Flixton}

As the climate warmed at the start of the Holocene, vegetation became re-established in the lake, leading to the resumption of marl formation within the basin and the start of organic sedimentation in the shallower lake margins. However, this was a transitional process, with the first evidence for warming starting 10055-9325 cal BC (95\% probability; start onset Holocene; Blockley et al. 2018, table S6), probably starting 9815-9415 cal BC (68\% probability) from the oxygen isotope records outlined in Chapter 18. This is in line with records across Northern Europe and the North Atlantic (e.g. Rasmussen et al. 2014), indicating a rapid shift in average temperatures, but with summer temperature rises being muted and unstable (between $10^{\circ} \mathrm{C}$ and $8^{\circ} \mathrm{C}$ ) for the first c. 250 years of the Holocene.

The level of the lake rose rapidly at the start of the Holocene and by 9635-9445 cal BC (94\% probability; onset organics 3178 Figure 17.22) or by $9430-9410$ cal BC (1\% probability), probably by $9580-9550$ cal BC (14\% probability) or 9535-9460 cal BC (54\% probability) the water level was at least $23 \mathrm{~m}$ OD, and probably closer to 23.5 $\mathrm{m}$ OD, high enough for aquatic plant material to be deposited in the accumulating organic sediments close to the shore at Star Carr (see Chapters 17 and 19). At this level the lake would have been present across much of the basin, filling the shallower embayments at Seamer Carr, Cayton Carr and Lingholme (Figure 4.4). Flixton Sites 1 and 2 (Flixton Island) would have been separate areas of dry land with a narrow area of shallow water between them, whilst deeper water lay between Flixton Island and No Name Hill. Star Carr itself lay on the southern shore of a large, hilly peninsula at the western end of the lake. The peninsula extended out into the lake at a point where the basin narrowed, creating a large embayment that led to the outflow channel to the west.

Pollen and plant macrofossils from the earliest Holocene deposits in Core B (Chapter 18) and the deeplake profile previously recorded by Dark (1998c), and the very earliest organic sediments at Star Carr (see Chapter 19) show that a range of aquatic and emergent plants were quickly becoming established in the lake. These included species of pondweed and the floating aquatic plant water milfoil (Myriophylum spicatum) and beds of the aquatic algae stonewort (Characeae), with emergent plants such as bogbean (Menyanthes trifoliata), and species of sedge (Carex sp.), bulrush (Typha sp.) and bur-reed (Sparganium) growing in shallow water along the shore (Dark 1998c, 169-170). Beyond the water's edge the pollen analysis indicates a largely open 


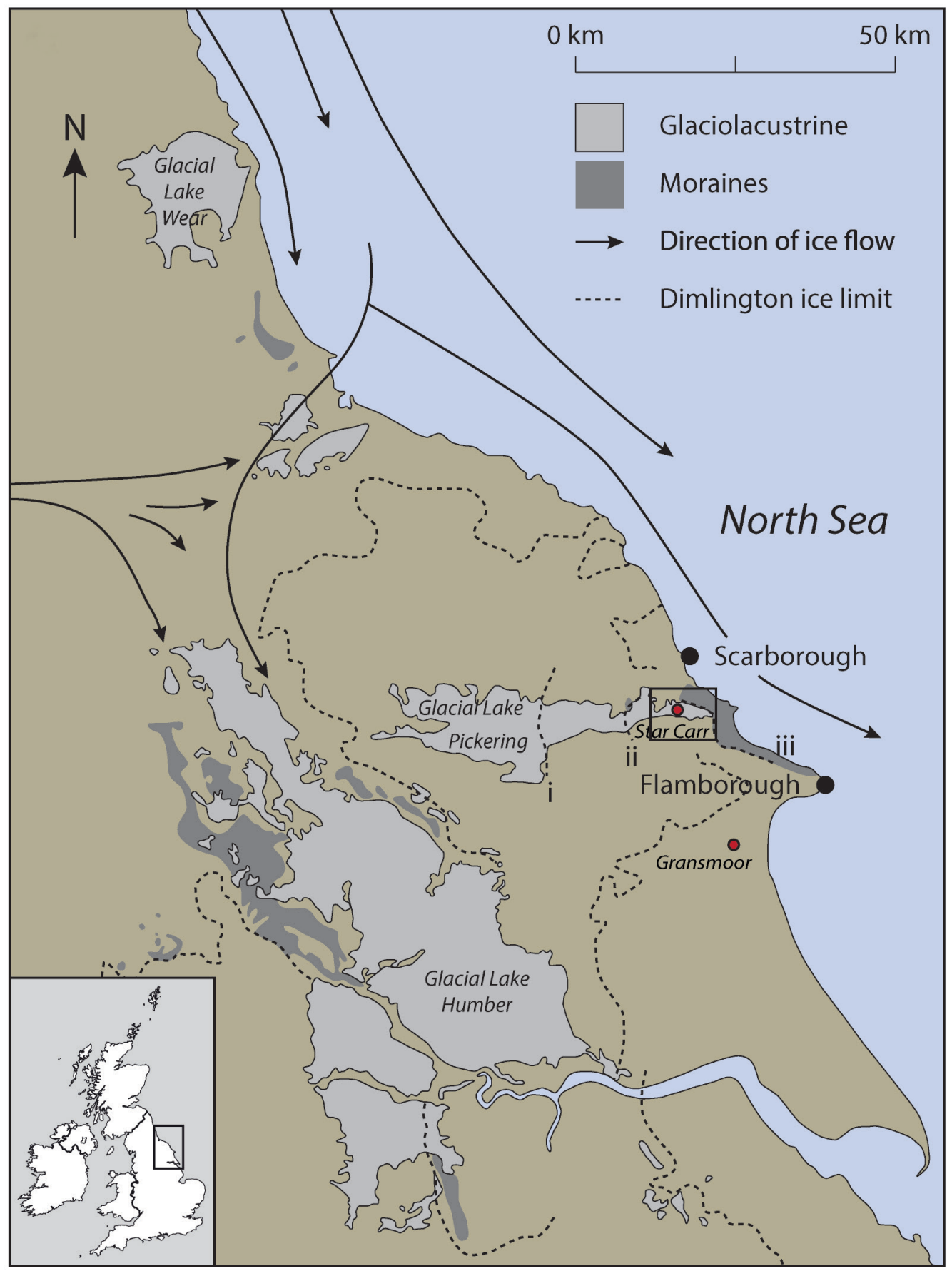

Figure 4.3: The regional context of Glacial Lake Pickering in relation to Glacial Lake Humber, adapted from Palmer et al. $(2015,51)$, including the models of the ice sheet extent in the Vale of York and extending along the east coast of Yorkshire and Lincolnshire. The maximum extent of the ice dam in the eastern end of the Vale is still debated and two maximum positions are shown. The first has the maximum of ice forming the Wykeham Moraine at position ii; the second, proposed by Foster (1985; position i), suggests the maximum position to the west of the Wykeham Moraine. Clark et al. (2004a) favour this latter position. Penny and Rawson (1969) suggest that the ice sheet retreated eastwards from Wykeham and stabilised to form the Flamborough Moraine at Position iii (Adapted from Palmer et al. 2015. Copyright (2015) with permission from Elsevier). 


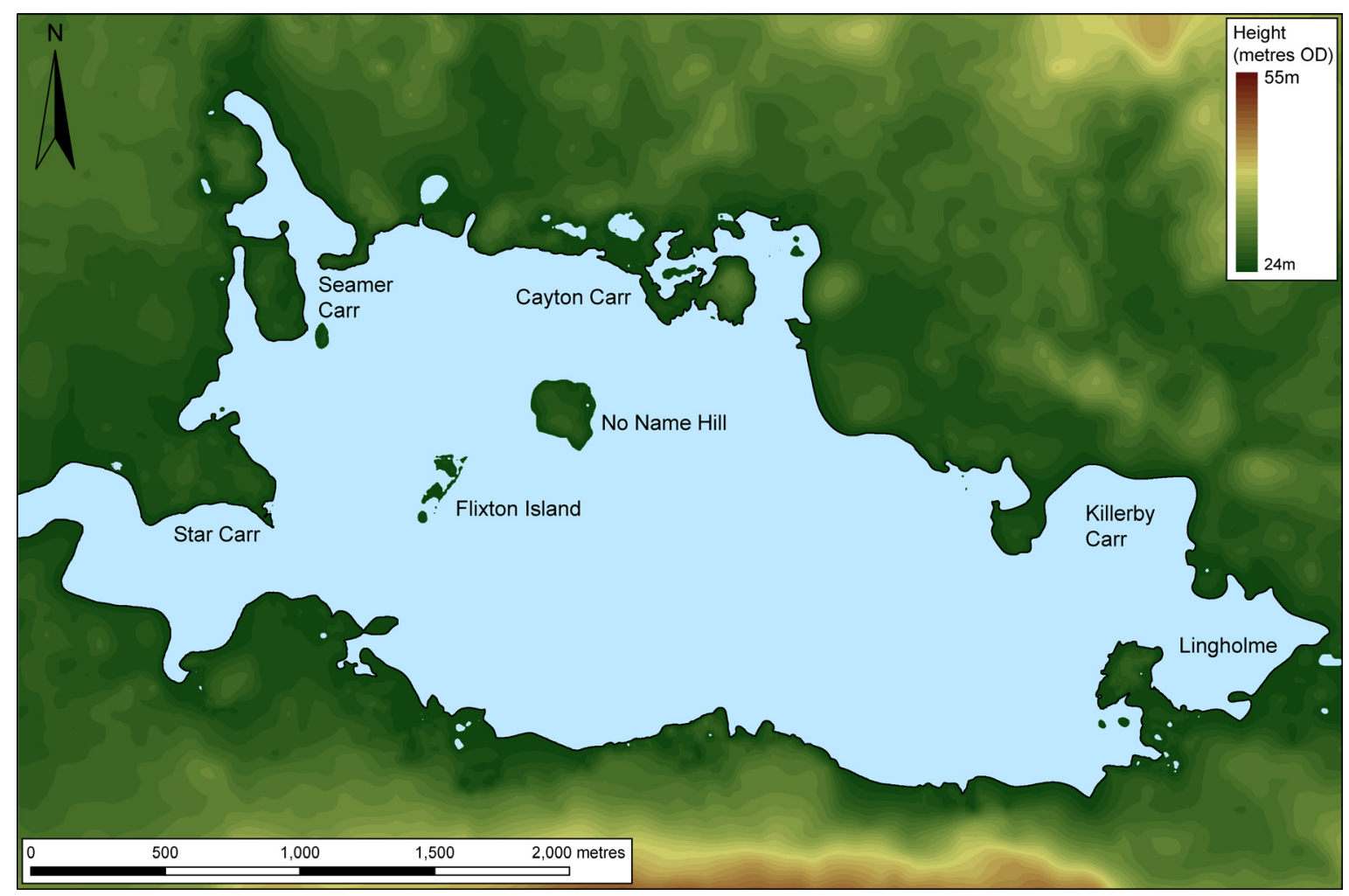

Figure 4.4: The Early Holocene Lake Flixton and surrounding topography (Copyright Barry Taylor, CC BY-NC 4.0).

landscape colonised by grasses, sedges, and tall herbs such as species of Filipendula (possibly meadowsweet), with areas of scrub, consisting of juniper (Juniperus communis), and species of willow (Salix) and birch (Betula) (Dark 1998c, 169; Chapter 18).

Though temperatures had warmed after the end of the Late Glacial Stadial, the Early Holocene climate was still highly unstable and at 10,025-9190 cal BC (95\% probability; Isotopic event 1 start; Blockley et al. 2018, table S6), probably at 9710-9255 cal BC (68\% probability) there was an Abrupt Climate Event (ACE 1), defined as a centennial scale abrupt climatic oscillation, seen within both the chironomid-based temperature reconstructions and $\delta^{18} \mathrm{O}$ values. ACE 1 is most strongly seen in the $\delta^{18} \mathrm{O}$ signal (decline by $\sim 2 \%$ ) but is also seen as a $1.5^{\circ} \mathrm{C}$ decline in chironomid based summer temperatures. ACE 1 is consistent with a similar climate oscillation in the Greenland ice cores at 11,400 BP (c. 9400 BC; Chapter 18). The cooler climate persisted for as little as 80-100 years (Isotopic event 1; Blockley et al. 2018, figure S18), ending with an equally rapid rise in temperatures shortly before the first evidence for the arrival of Mesolithic groups.

\section{The Early Mesolithic environment}

Based on the plant macrofossil and insect data from Star Carr (Chapter 19), and other sites around the lake (Taylor 2012), wetland environments were already established around the lake by the start of the Mesolithic (environmental zone 1; Chapter 19). Reedswamp environments, consisting of Phragmites reeds, bogbean, clubrush, and species of sedge, bulrush, and bur-reed were present in standing water around much of the shore (Figure 4.5a). The lake level now lay at c. $24 \mathrm{~m} \mathrm{OD}$, placing areas of emergent vegetation in up to a metre of water. Beyond the reedswamp, communities of floating and submerged aquatic plants, particularly water-lily and species of pondweed, were growing in the deeper water, possibly with stands of emergent plants such as club-rush. At the shore, fen vegetation, such as gypsywort (Lycopus europaeus) and nettles (Urtica dioica) grew on the damp soils, amongst ferns, shrubs and trees, particularly birch and aspen (Figure 4.5b). Away from the 

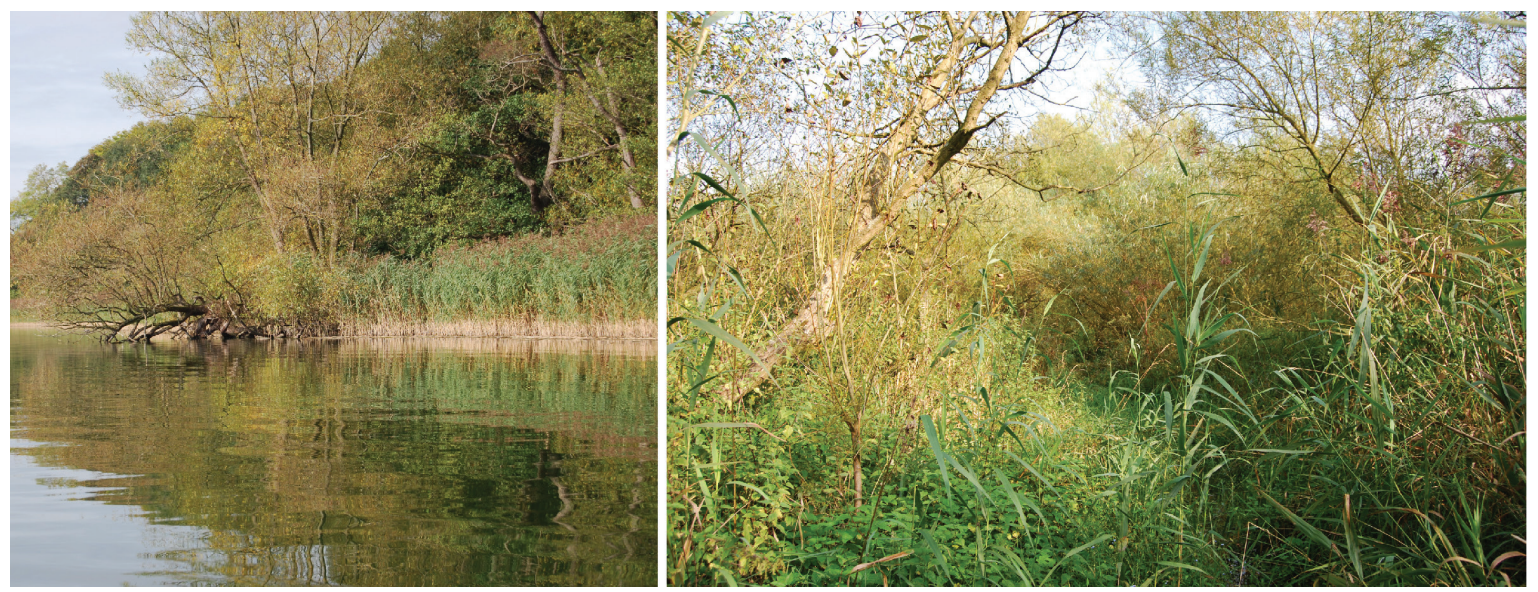

Figure 4.5: Lake edge reedswamp (a) and willow carr (b) at Rostherne Mere, Cheshire (Copyright Barry Taylor, CC BY-NC 4.0).

lake edge, the pollen record shows that the landscape remained open, with extensive areas of open ground covered with grasses and tall herbs, and more localised areas of scrub and isolated tree cover (see Chapter 18). However, from the archaeological record we know that areas of more dense woodland, that included birch, willow and aspen, were established by the start of the Mesolithic, probably forming discrete patches within the otherwise open landscape (see Chapter 6).

The wetland environments were highly diverse, varying in both their extents and species composition across the lake. Differences in the plant macrofossil assemblages suggest that the spatial distribution of particular species was uneven. Bur-reed, for example, is better represented in the assemblages from the north shore of No Name Hill than at other sites around the lake (Taylor 2011,74), whilst yellow water-lily is more common at Star Carr (see Chapter 19). Spatially, the extents of the wetlands would have varied as differences in the topography of the basin created localised differences in water depth. This would have created extensive areas of reedswamp in the shallow embayments at Seamer Carr, Lingholme and Cayton Carr as well as the shallower stretches of lake edge, whilst in areas such as Killerby Carr, where the basin falls away rapidly, a much narrower fringe of vegetation would have separated the shore from the areas of deeper water (Taylor 2012, 438) (Figure 4.6). Though it is much harder to identify such variability on the terrestrial landscape it is likely that these areas were equally diverse, with discrete areas of birch, willow and aspen woodland, and juniper and willow scrub forming amongst areas of grassland and tall herbaceous plants.

The character of these environments changed throughout the early centuries of the Mesolithic. Across the terrestrial landscape, juniper scrub became more extensive, expanding over the areas of more open grassland, before a second abrupt climate event (ACE 2) occurred at 9665-9030 cal BC (95\% probability, Isotopic event 2 start; Blockley et al. 2018, table S6), probably at 9380-9090 cal BC (68\% probability). ACE 2 is clearly expressed in the $\delta^{18} \mathrm{O}$ signal (decline by $\sim 1.5 \%$ ) and the chironomid based summer temperature record $\left(1.5^{\circ} \mathrm{C}\right.$ ). It is notable that this event was of the magnitude of other Early Holocene shifts such as the $8.2 \mathrm{ka}$ BP event (c. 6200 $\mathrm{BC}$ ); a later occurrence of climatic instability commonly thought to have negatively affected Mesolithic human populations. ACE 2, recorded at Star Carr, is coincident with an event recorded in the Greenland ice core NGRIP at $11.1 \mathrm{ka} \mathrm{BP} \mathrm{(c.} 9100 \mathrm{BC}$ ) (but not in GRIP or GISP). It is also noted in records across Europe and may be a more isolated European phenomena. ACE 2 is associated with a vegetation response with a decline in birch and an expansion of grasses and other herbs, alongside peaks in Pediastrum and pre-Quaternary spores, both of which are suggestive of increased inwash of nutrients and derived material into the lake basin. Both of these indicators suggest increased landscape instability.

Shortly after this event, birch woodland became more established, replacing the environments of juniper scrub and the remaining areas of more open grassland (Chapter 18). This transition was rapid, occurring in a matter of decades, during which the terrestrial environments would have been both dynamic and spatially varied as areas of scrub, woodland and open grassland shifted and changed across the landscape. 


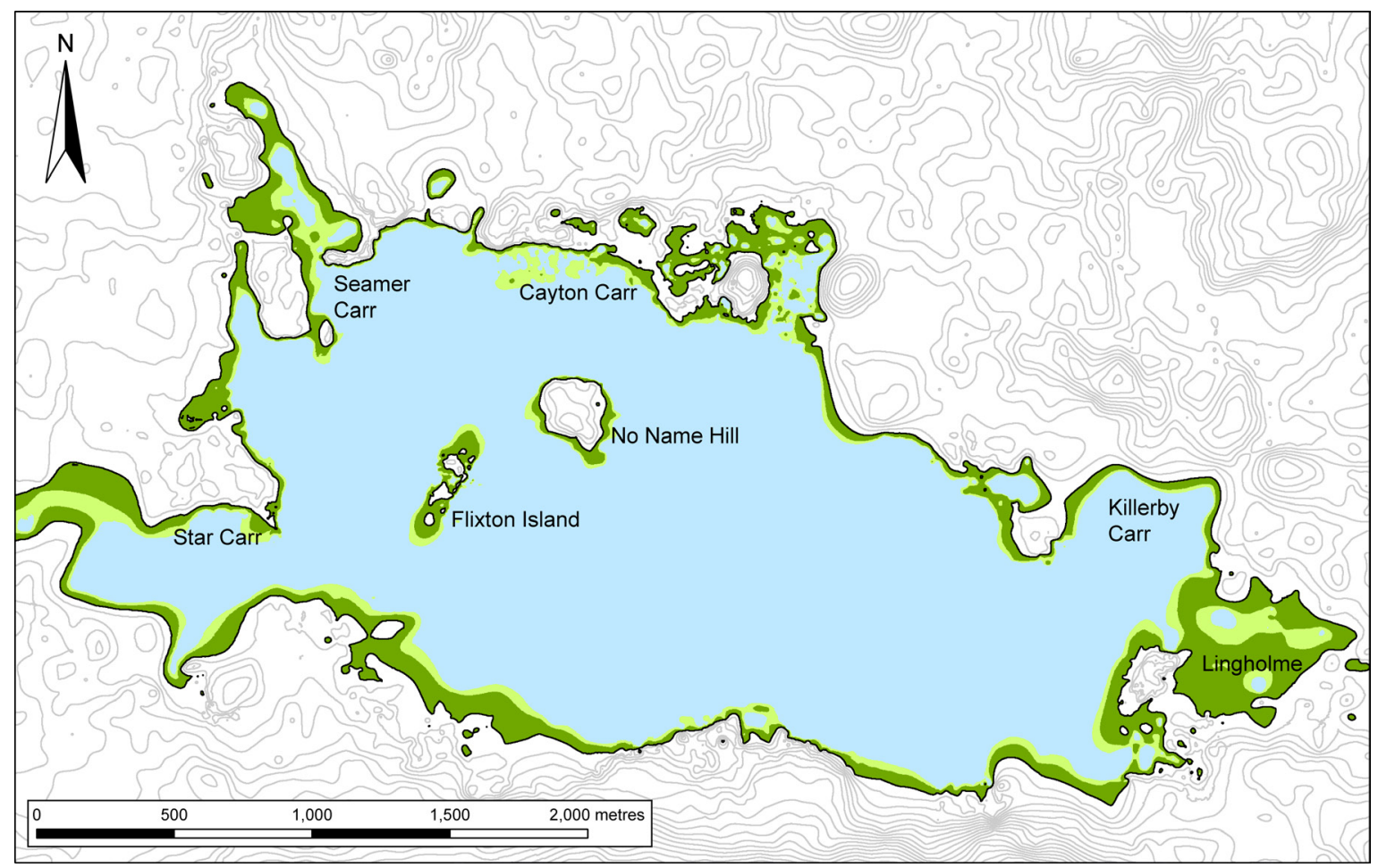

Figure 4.6: Approximate extents of the aquatic and reedswamp environments at the start of the Early Mesolithic (Copyright Barry Taylor, CC BY-NC 4.0).

Within the basin, the formation of organic and carbonate sediments caused the depth of water within the lake to shallow. This allowed plants suited to shallower or seasonally flooded environments to colonise the lake edge areas whilst reeds and other species tolerant of deeper water expanded further into the lake. At Star Carr, this process was underway from around $9145-9010$ cal BC (95\% probability; first EZ2, Figure 17.22), probably in 9125-9055 cal BC (68\% probability) as the amount of water reaching the lake edge peats declined and sawsedge began to grow across the site, along with sedges and Phragmites reeds (start of environmental zone 2; see Chapters 17 and 19). The same changes occurred several centuries later within the main body of the lake (e.g. Taylor 2012,184) perhaps a result of different rates of organic sedimentation within this part of the basin.

By $8795-8605$ cal BC (95\% probability; first EZ3, Figure 17.22), probably by $8750-8655$ cal BC (68\% probability) the ongoing accumulation of organic sediments at Star Carr had begun to form beyond the reach of the lake water (see Chapters 17 and 19), and comparable conditions were becoming established in the main part of the basin shortly after (Taylor 2012, 440). A fen environment of grasses, ferns and tall fen herbs began to grow on the peat at Star Carr, with trees encroaching on the wetlands edge, whilst a denser carr of willow and aspen formed around other parts of the shore (Taylor 2012, 187) (Figure 4.7). However, these areas remained wet and boggy, and continued to be affected by occasional flooding, whilst small areas of standing, stagnant water persisted in places. At the same time, aquatic and swamp vegetation expanded further into the lake, creating a more expansive wetland environment. At the site of Flixton School House Farm, on the southern edge of the basin, aquatic plants and stands of emergent vegetation were growing at least $50 \mathrm{~m}$ from the former shore (Taylor 2012, 204-5) and comparable environments were probably present at Star Carr and in other, shallower parts of the lake. The shallow embayments at Seamer, Cayton and Lingholme were probably largely infilled by this date, creating extensive areas of fen and carr with isolated patches of reedswamp (Taylor 2012, 440) (Figure 4.8).

In the centuries that followed the end of human activity at Star Carr, the character of both the wetland and terrestrial environments began to change. Hazel became established as the principal arboreal taxa (Dark 1998c, 170), and its denser canopy shaded out much of the fern understorey and reduced the diversity of the woodland ground flora. Within the wetlands, the areas of willow and aspen carr that had formed over the peat at the edge 

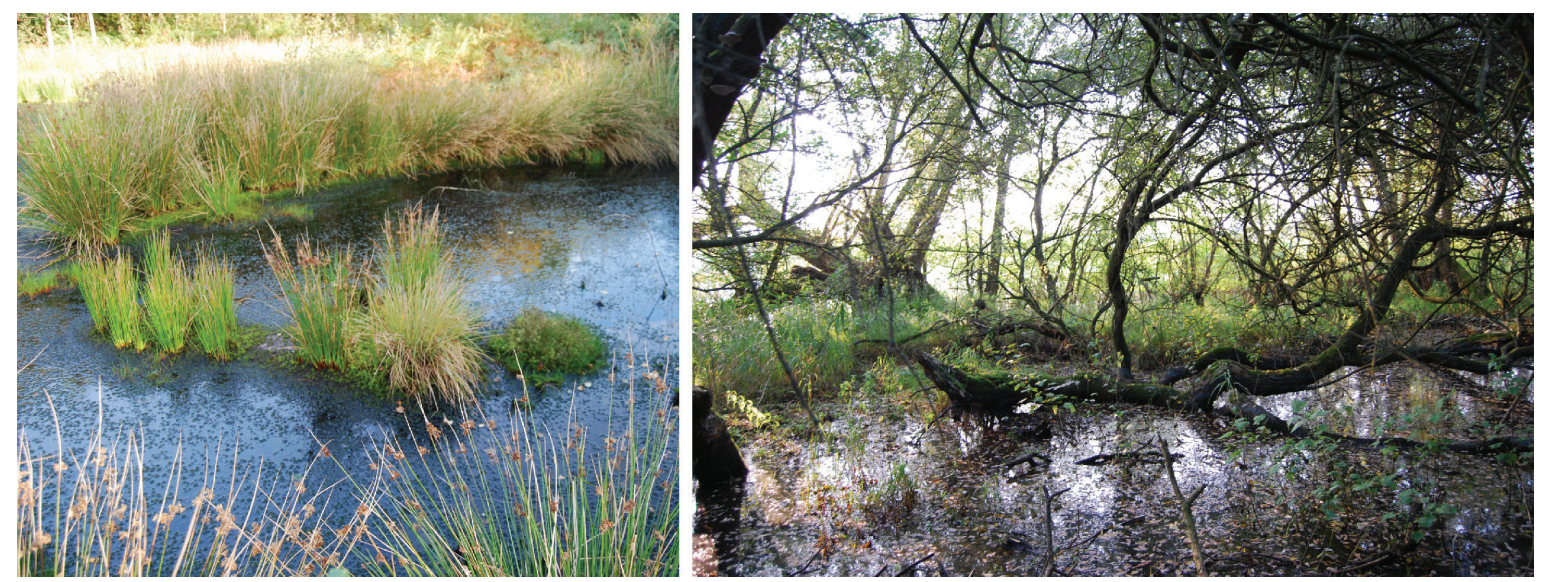

Figure 4.7: Rushes growing in pools of water in an in-filling lake edge (Doolittle Moss, Delamere, Cheshire) (left), and willow carr forming over lake edge peat (Rostherne Mere, Cheshire) (right) (Copyright Barry Taylor, CC BY-NC 4.0).

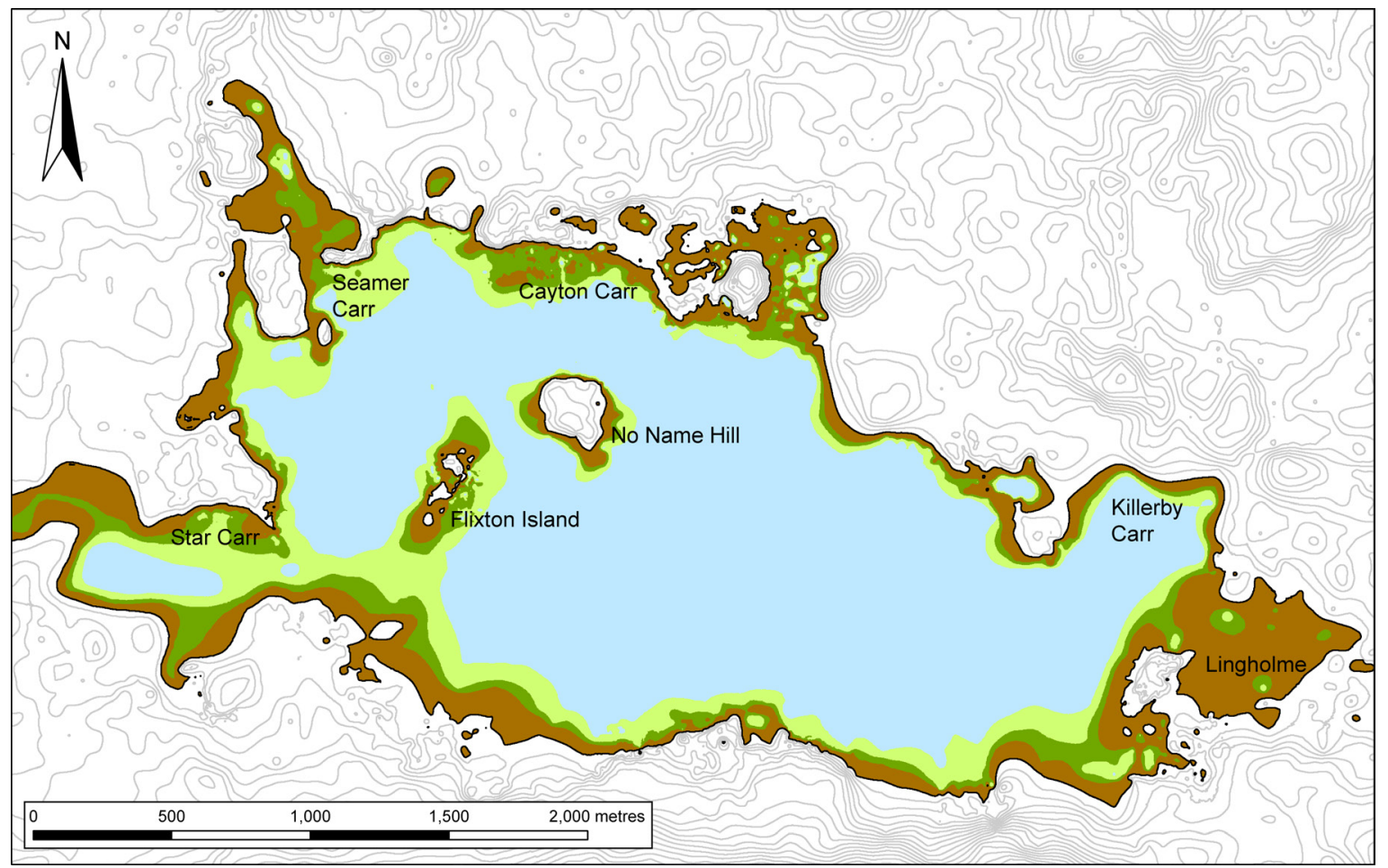

Figure 4.8: Approximate extents of the wetland environments c. 8500 cal BC (Copyright Barry Taylor, CC BY-NC 4.0).

of the former lake were replaced by a more open fen environment, an event dated at sites along the southern shore to the centuries around c. 8000 cal BC (Taylor 2012, 188; 10000 BP) (Figure 4.9).

At around the same time peat-forming wetlands began to expand over areas of previously dry ground beyond the lake shore, gradually burying lower-lying areas around the basin (Figure 4.9). Based on the composition of the peat, these environments consisted of tall fen herbs, ferns and sedges or grasses (Taylor 2012, 195). At Star 


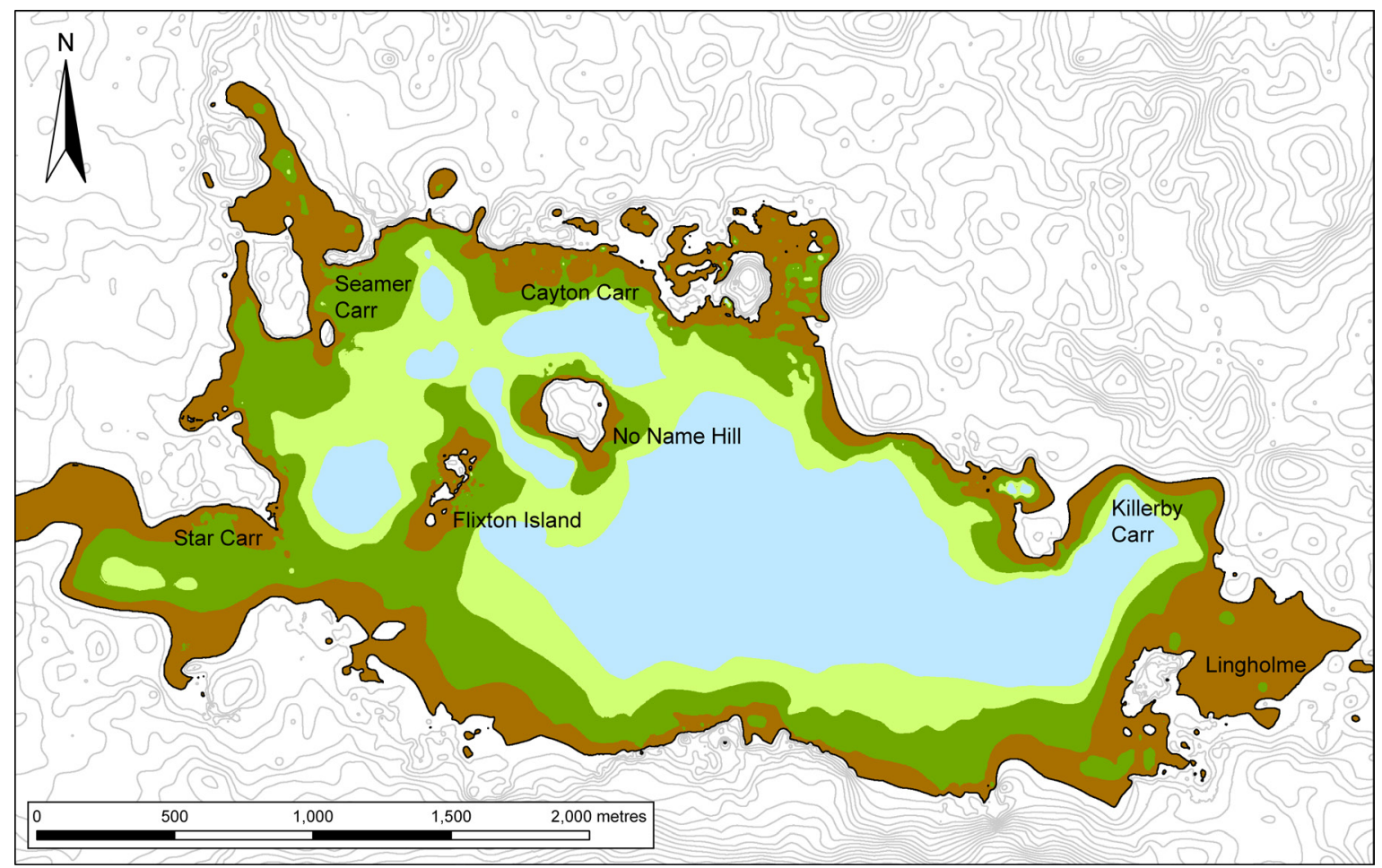

Figure 4.9: Approximate extents of the wetland environments c. $8000 \mathrm{cal} \mathrm{BC}$ (Copyright Barry Taylor, CC BY-NC 4.0).

Carr, dates obtained by Cloutman in the 1980s show that these terrestrial wetlands had reached the $25 \mathrm{~m} \mathrm{OD}$ contour over the southern extent of the Star Carr peninsula in the centuries around c. $7800 \mathrm{cal}$ BC (9800 BP), and had reached a similar elevation across the steeper slope along the east of the peninsula several centuries later (based on the dates in Cloutman 1988a, 15 Table 1).

The causes of these changes are unclear. There is no evidence for a significant rise in the level of the lake at this time and aquatic material is entirely absent from the peat forming over the areas of dry ground (Taylor 2012 , 195). However, it is possible that a slight rise in the local water table, following on from the rises at the start of the Holocene, made conditions at the former lake edge too wet to support the growth of trees and led to the adjacent dry ground becoming waterlogged triggering the growth of peat in these areas (a process known as edaphic paludification).

The expansion of peat-forming environments over areas of dry ground would have altered the character of the landscape significantly and had a profound effect on the lives of its inhabitants. Occupation sites on areas of low-lying ground, such as Star Carr, would have been abandoned as fen began to encroach over them, and sites on the low hilly peninsulas around the edges of the basin would have become islands within the gradually expanding wetlands (Figure 4.10). Trees may also have receded on to higher, drier ground, leaving a large belt of open fen, between the hazel dominated woodland and the areas of reedswamp and open water within the basin.

In the deeper parts of the basin, the depth of water continued to shallow due to the ongoing accumulation of sediments, allowing wetland environments to become more extensive. At Flixton School House Farm, on the southern shore of the lake, terrestrialised fen environments had extended over $50 \mathrm{~m}$ from the shore by around c. $7200 \mathrm{cal}$ BC, with stands of emergent vegetation growing amongst aquatic plants in what had formerly been deeper water over $300 \mathrm{~m}$ further into the basin (Taylor 2012, 208). In the following centuries this area also became terrestrialised, whilst swamp environments began to extend further into the lake.

Apart from short-lived fluctuations in the local water table, the wetlands continued to develop in a broadly linear manner throughout the next millennia, with swamp environments reaching some of the deeper parts of 


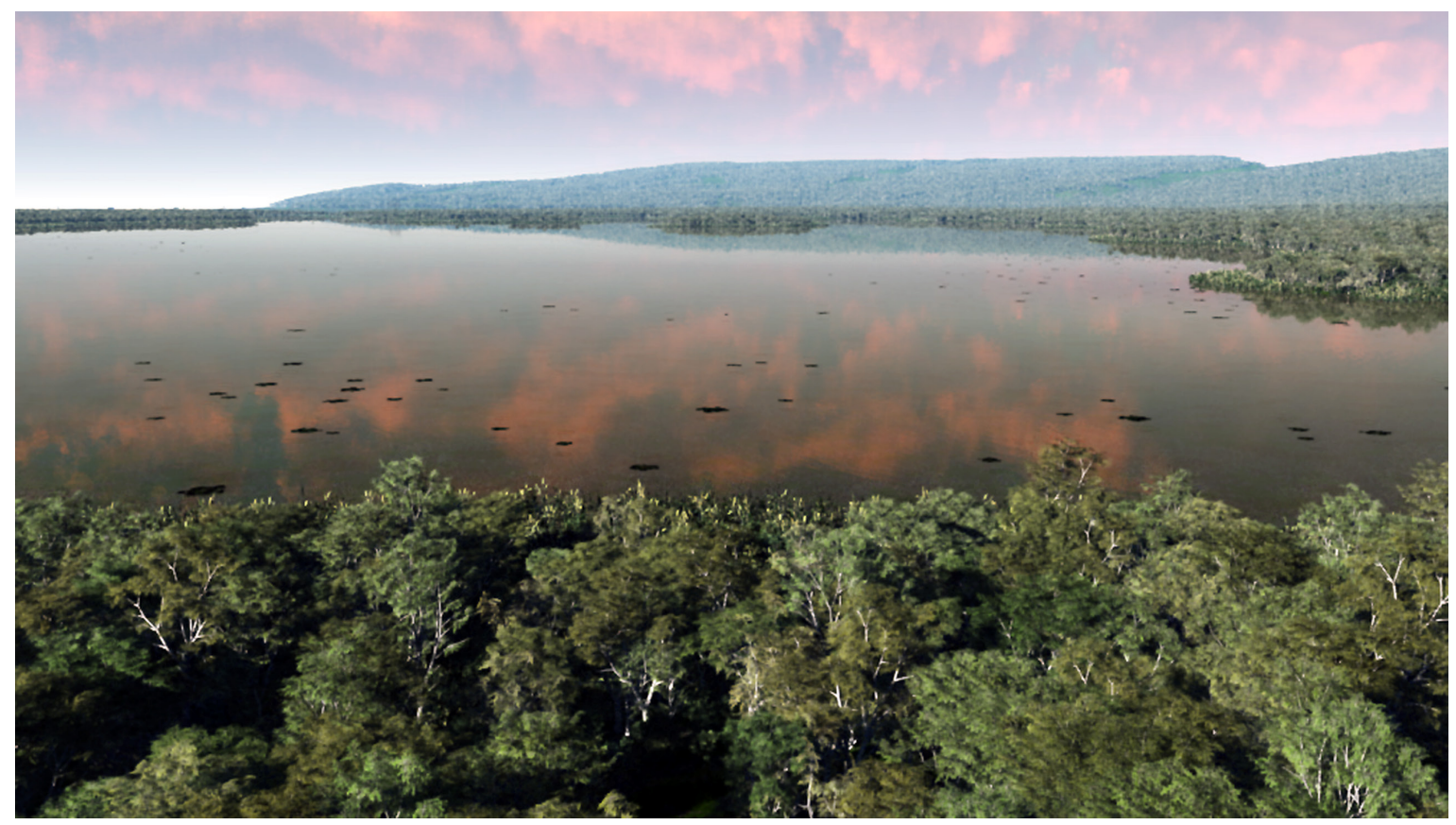

Figure 4.12: A reconstruction of what the lake may have looked like during an early phase of occupation at Star Carr (Copyright Anthony Masinton, CC BY-NC 4.0).

To watch this video, scan the QR code with your mobile device or visit DOI: https://doi.org/10.22599/book1.1

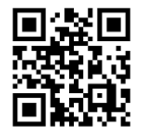

the basin, and peat-forming wetlands encroaching onto increasingly higher ground (Taylor 2012, 448). Alder was becoming established around the lake from 6660-6360 cal BC (94\% probability) or 6290-6270 (1\% probability) (7640 \pm 85 BP OxA-4042; Dark 1988c, 170), and was growing locally at No Name Hill and Flixton School House Farm in the centuries around c. 5300 cal BC (Taylor 2012, 191). By this date, the lake had ceased to exist as a substantial body of water and had been replaced by a mosaic of fen, swamp and carr, with standing water restricted to discrete pools, probably colonised by emergent plants and fringed by shrubs and trees (Figure 4.11). Peat-forming environments had reached at least as far as the $26.5 \mathrm{~m}$ OD contour, leaving the Star Carr peninsula and many of the other Early Mesolithic sites buried beneath thick deposits of peat (Taylor 2012, 194). Beyond this wetland, a mixed deciduous forest of oak, elk, ash and lime covered much of the dry ground (Dark 1998c, 170).

\section{Conclusions}

A reconstruction of Lake Flixton has been created, providing some idea of what the landscape might have looked like about 11,000 years ago (Figure 4.12). However, the climatic and environmental history of Lake Flixton is highly dynamic. The Early Holocene, including the period when Star Carr was inhabited, was a time of significant change with abrupt shifts in climate and relatively rapid developments in the environments of the

Figure 4.11 (page 52): Tussocks of sedge and rush surround pools of open water in an in-filled basin (Doolittle Moss, Delamere, Cheshire) (Copyright Barry Taylor, CC BY-NC 4.0). 
lake and the surrounding landscape. These environments were also diverse, varying in their nature and extent across the lake. Some of these changes would certainly have been noticeable to the communities of huntergatherers who inhabited this area. This is particularly true of the episodes of climatic change, which would have occurred within people's lifetimes. However, it is only by relating the environmental and climatic records with the well-dated archaeological sequences from Star Carr that we can start to consider the effects that these changes had on people's lives, as we show within the following chapters of this book. 